\title{
機能性繊維「フレシール
}

\section{FRAICHIR, Functional Textile}

塩 見秀 数・山田英幸

1.はじめに

角はフィブロインとセりシンというタンパタ筫からをり， 七リシンはフィブロインのまわり在取り囲んで存在してい る(写真 1 ).

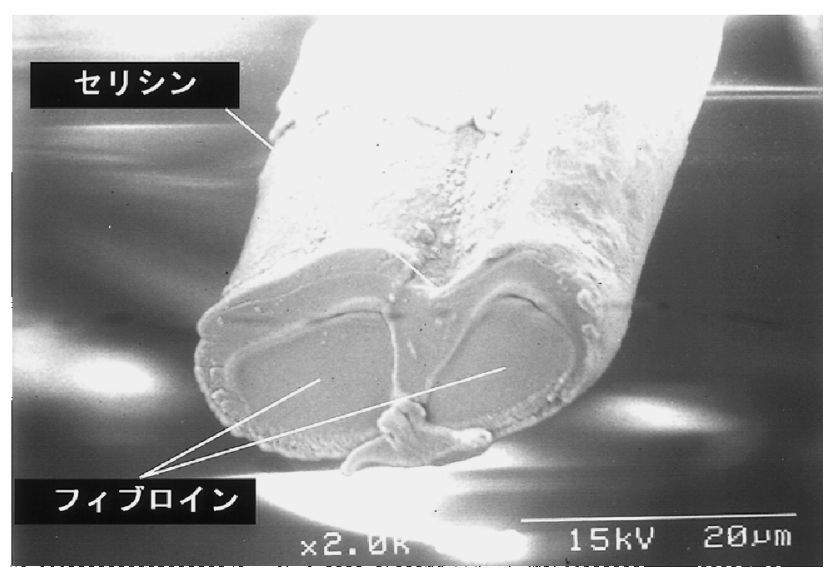

写真 1 生杀 0 断面図

絹(シルク)に関するこれまでの研究は，フィプロイン军 中心とした妍究が主流であった。当社くは，セリシンの有 約性について研究在進めて打り，セリシン老䋊維表面に定 着㞦工する技術存開発し，展開している。今国洁，このせ リシン定着瀻稚「フレシールさ在紹介する。

\section{2. セリシンの栱能}

せリシンの倳能として，保湿効果，抗酸化能，美白郊果 が挙げられる。

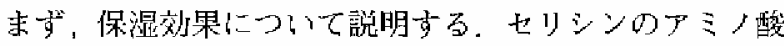
組成は，水酸基老持つセりンが $30 \%$ 以上心故り，スレ才 ニンと合計す尚と約 $40 \%$ 加ヒドロ文シアミノ酸加らなっ ている。去た，非極性アミ八酸の割合加 $15 \%$ 程度で非常

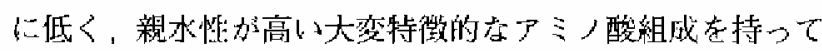
いる。このセリシンのアミノ酸悢成は，攴皆の天然保湿因

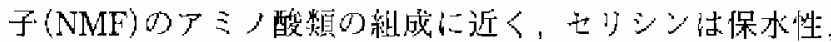

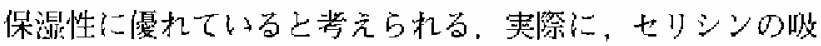
湿率を測芫した結果をるる。，化粧品用の保湿削として沨 用されているフィブロイン，コラーダンよりもセリシンの 吸湿詨果が大き。

続いて，䖽のさなき守守ディフェンスタンパタという

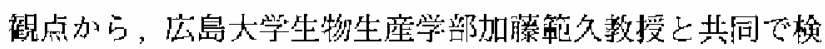

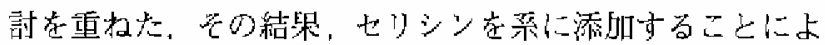

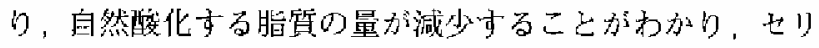
シンの杭酸化能颃確認さ扎た。

つきに，メラニン色菜の生成に関与占䣲素手口シナ一 ゼに詨する阻害效果の㭲討在行った。矢の結果，七りシン 添加によりチ日シナ一ゼ活性の有意な低下が見られ，セリ シンの美白勃果が諗められた。

\section{3. セリシン定着維維「フレシール危!}

当社ては，このような特徽を有するせリシンで戴維表面

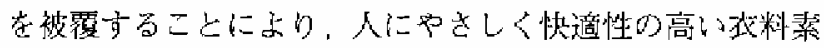

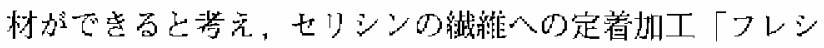
一儿思」老開発した。

\section{(1)「フレシール㝵」の情能}

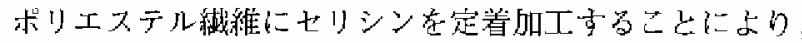

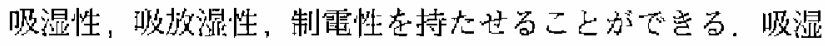

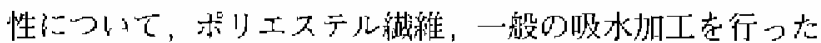

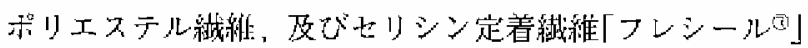

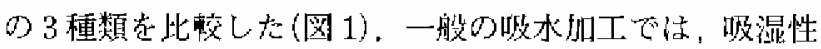

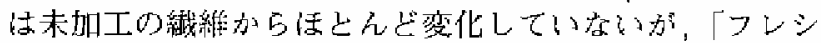

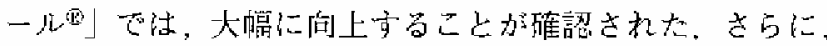
「フレシールツ」は，高湿度下と低湿度下での䏜湿率の差

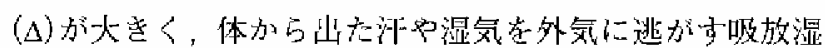
性に隕机ること仿わかる。

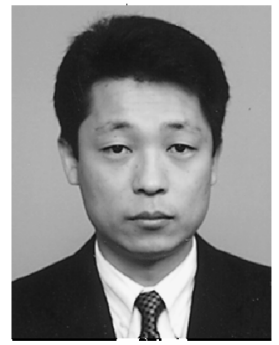

HIDEYUKI YAMADA

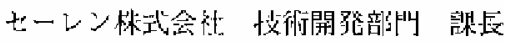

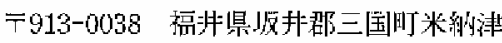
$48-113-2$

Tel : 0776-82-7006

e-mail : h.yamada@seiren.co.jp 〈専門〉天然高分子、蛋白質沁朋 


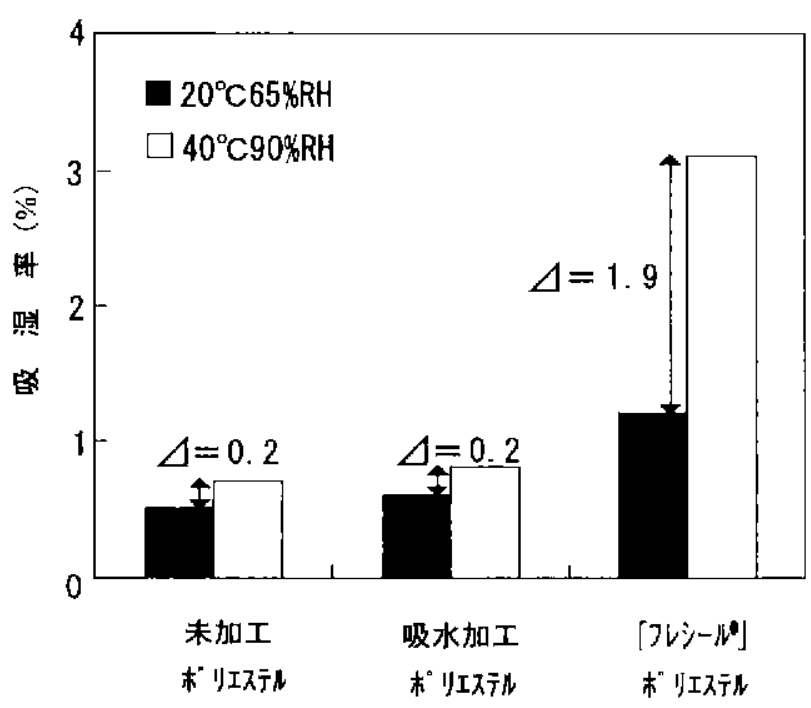

図1吸放湿性の比校
(2)「フレシール依」の皮虞への效果

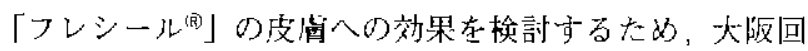

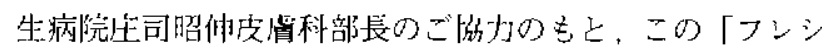
ールの」繊維に與味をもっていただな热者の皆様のごす 解を得て着用試験を行った。

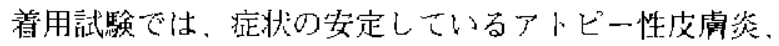

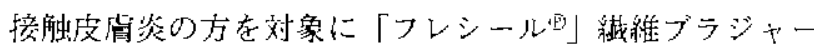
を 1 ケ以上着用していただき，着用による症犾の﨎化を 調心゙た。その結果，担当医饫による将状の観察に拓いて改 羓少認められた。 未た，偲者自身に回答していたたいた着 用アンケートの結果(図 2)に扰いても，「フレシール(P)」緎 稚ブラジーが接触する趴分に有意に改善が認められ，增 舁した聇例は一つもなく. $80 \%$ 以上の患者が「フレシー

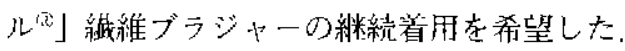

\section{4、まとめ}

当社は，セりシンの機能を明らかにし，䄉䑾分野をはは心 めとする様々な用途(化粧品や住品)に展開を行っている

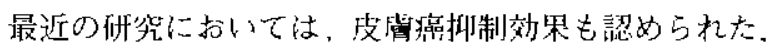

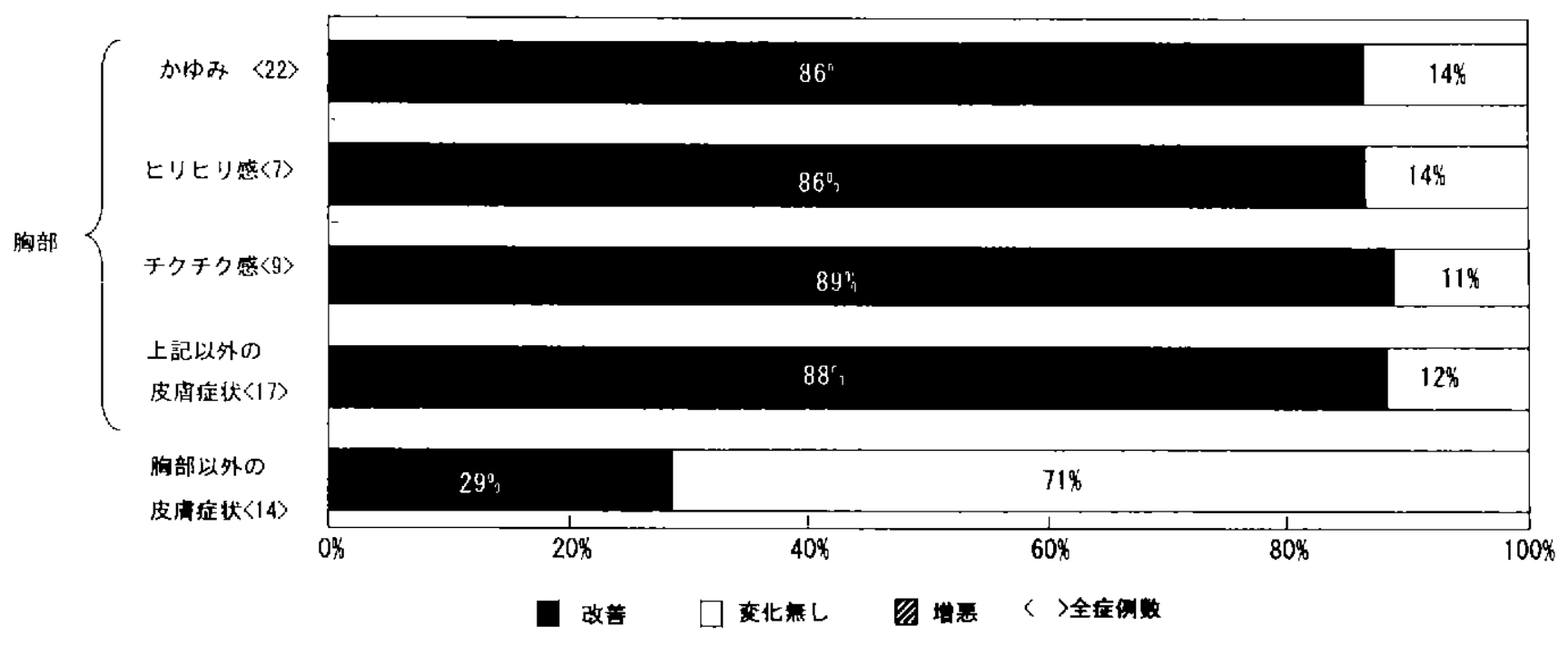

図 2 「フレシール可」者用アンケートからの改善率 